\title{
Divorce: Men Do Not Hold all the Cards- The Qur'an Actually Levels the Playing Field Through Mandated Process and Etiquette
}

\section{Qur'anic Verses on Divorce}

Divorce is a huge topic of concern for God in the Qur'an, which devotes a significant number of consecutive verses to it in its Chap. 2 as well as the first several verses of its chapters 58 and 65 , alongside a handful of other scattered verses. Even as He makes clear that it is His least-favourable solution to marital discord and even as He counsels a period of reflection and even recommends mediation, God makes explicit His commandment that the divorce process be kind and fair in contrast to the then-prevailing customs, reflecting a clear preoccupation with protecting those whom $\mathrm{He}$ saw as the underdogs in the equation: women.

The discourse begins by addressing the pre-Qur'anic custom where a man would swear off sexual relations with his wife yet not divorce her, leaving her in limbo, often for years: ${ }^{1}$

\section{The Cow, 2:224-228}

Do not use God as an excuse in your oaths for not being good and reverent and making peace between people; for God is all-Hearing, all-Knowing.

God will not take you to task for oaths uttered without thought, but He will take you to task for what your hearts have earned. For God is all-Forgiving, Clement.

${ }^{1}$ Nasr, Seyyed Hossein (editor-in-chief) et al. 2015. The Study Quran: A New Translation and Commentary. New York: HarperCollins Publishers, 98.

(C) The Author(s) 2022

L. El-Ali, No Truth Without Beauty, Sustainable Development

Goals Series, https://doi.org/10.1007/978-3-030-83582-8_15 
Those who forswear their wives must wait four months, and if they go back (on their oath), truly God is all-Forgiving, ever-Merciful.

But if they decide upon divorce, truly God is all-Hearing, all-Knowing.

$\checkmark$ Divorced women must wait alone [i.e. not re-marry] for three menstrual cycles, and it is not lawful for them to hide what God may have created in their wombs, if they believe in God and the Last Day. And their husbands would be more just (abaqq) in taking them back in that case if they (the husbands) want to fix things (islab). Women are due the same as what they owe in kindness (bil-maaroof), and men a degree more than them. For God is Mighty, Wise. (2:228)

Bizarrely, the last verse above, $2: 228$, is the second most-cited verse by those arguing that the Qur'an itself says that men are superior to women (the most cited verse being 4:34 as already discussed under Guardianship and Participation and which we will come back to in Part V). The reason is that even in Arabic, this verse can be understood completely differently if it is read in isolation from its neighbouring verses and with a pre-disposition to think that men are more important than women in God's eyes. The penultimate sentence in particular is of issue here, though the other three I have also underlined above also play a part, depending on the interpretation or translation, which typically conveys the following:

$\times \quad$ The Cow, 2:228

Divorced women must wait alone for three menstrual cycles, and it is not lawful for them to hide what God has created in their wombs, if they believe in God and the Last Day. And their husbands have the better right to take them back in that case if they (the husbands) desire reconciliation. Women have similar rights to the rights against them according to what is equitable/ reasonable, and men are a degree above them. For God is Mighty, Wise.

This usual interpretation is unconvincing in my view if only because it completely breaks away from the direction in which the four preceding verses appear to be heading:

- First, remember that the two verses just before this one speak of situations where men abstain from their wives unfairly, and counsel a period of reflection (four months) before a final decision must be made, so that 2:228 is actually telling us what should then happen if the husband chooses divorce. 
- Second, notice the difference in nuance between "would be more just" and "have the better right" (ahaqq), between "fix things" and "desire reconciliation" (islah): since this group of verses seeks redress for wives against an unfair abandonment practice by husbands at the time, doesn't the first interpretation offering men a path back to justice make a lot more sense than the second (usual) interpretation that appears to suddenly extend men preferential rights of firstrefusal in this very matter where they have acted cruelly?!

- Third, there is a world of difference between acting "kindly" (bilmaaroof) as opposed to the common translation "equitably/ reasonably".

- Fourth, with regard to the penultimate and most critical sentence which is literally equivalent to "though men a degree more than women", I simply ask the reader to reflect on which is the more likely meaning in the context of the flow of the argument God is making here over these five verses, where He is seeking to redress the imbalance of a custom that left wives vulnerable (while acknowledging that husbands still had the free will to choose divorce), going so far as to spell out that women's rights are the same as men's rights in marriage: why would God suddenly capsize His own argument by declaring, after all this advocacy, that husbands "are above" wives rather than that "they owe more kindness" since they are the providers and because of the additional burden carried by women just mentioned in 2:228 itself, namely pregnancy and all that comes with and after it?

- Lastly, it must be said by way of a general observation that the traditionally patriarchal interpretations appear to steer the spousal relationship towards the transactional realm, whereas there is nothing transactional in the concept of doing something with kindness and/or honourably (with maaroof) by definition, a word repeatedly deployed by God in the Qur'an when speaking of divorce. Like so much else in the Qur'an, divorce is addressed in values-driven language, if we can but hear it once again.

And the flow continues:

The Cow, 2:229

Divorce is [revocable] twice [i.e. during the waiting period], after which (a wife) must be maintained in honour or released in a goodly manner. And it 
is not lawful for you (men) to take away any of what you had given them (the women) save when both fear not abiding by God's boundaries [i.e. of companionship, intimacy, fidelity and no abuse ]. ${ }^{2}$ So if you (the community) have reason to fear that the two of them will not abide by God's boundaries, then there is no blame on either of them if she offers something to free herself...

In 2:229 above, the Qur'an is safeguarding against husbands declaring divorce lightly or flippantly, proclaiming divorce and then changing their minds too frequently, thereby subjecting wives to endless cycles of pregnancy-check waiting terms that prevent them from moving on. ${ }^{3}$ Importantly, a husband cannot reclaim the bridal gift when he divorces his wife, and if it is the wife that wants a divorce, basically if he is resistant she can get her divorce unilaterally ( $\mathrm{khul}$ ) by giving him back his bridal gift in full, if a partial offer does not do the trick. In modern times, this would be the equivalent of returning the solitaire ring or bridal jewellery set, for example.

The Cow, 2:230-2:233

So if he divorces her [permanently, by re-confirming his intention at the end of the term], then she is no longer lawful for him (to re-marry) until she has (first) taken another man as husband. Then if he [the latter] divorces her, there is no blame on either of them if they get back together, if they both think they can abide by God's boundaries...

And when you divorce women and they have reached their waiting term, then either retain them honourably or release them honourably. But do not retain them in order to cause harm and transgress, and he who does that will have wronged [or sinned against] himself...

And when you divorce women and they have reached their waiting term, do not prevent them from (re)marrying their husbands if they have reconciled with one another with kindness (bil-maaroof). This is a warning for him who believes in God and the Last Day. That is more virtuous for you (pl.), and purer, for God knows and you (pl.) know not.

And (divorced) mothers may nurse their children for two whole years, for those who wish to complete the nursing period, and it is for the father to provide for them (the women) and clothe them, with kindness (bil-maaroof). No soul is tasked beyond its capacity. A mother must not be harmed on

${ }^{2}$ Ibid., 100.

${ }^{3}$ Ibid., 101. 
account of her child, nor a father on account of his child. And the same duty [of support] is incumbent upon the (father's) heir. And if they both wish to wean (the child) by mutual consent and consultation, there is no blame on either of them. And if you (pl.) wish to entrust your children to fosternurses, there is no blame on you so long as you hand over what you bring with kindness (bil-maaroof)...

In 2:233 just above, the Qur'an moves on to what should happen when the divorcing parents have infant children, spelling out the father's minimum alimony contributions towards his ex-wife (up to weaning of the infant): alimony to an ex-wife that is unrelated to children is formally established later in 2:241 (see below) but not specified quantitatively, which is why it is important for a bride and her family to bear in mind that in the Qur'anic system, the bridal gift can consist of a pre- and a post-marriage gift within the marriage contract, which I highly recommend for avoidance of future conflict. As for the mention of fosternursing, this is not surprising: it was common among the great families of Arab towns at the time to send their new-born sons into the desert to be nursed and raised (up to around eight years) by foster-mothers among the nomadic Arabs, or Bedouins, where they could acquire the desired qualities of nobility and freedom through "fresh air for the breast, pure Arabic for the tongue, freedom for the soul". 4

The Qur'an never addresses the question of custody of the children as such, but various verses make clear that providing for the children remains the father's responsibility regardless. I grew up with the understanding that children of divorced parents remain with their mother only until puberty, which I always assumed must have come from the seventhcentury custom of considering puberty to be the eligible age for marriage, so that good marriages can be effected by the father, who would have been viewed as the more capable power-broker. Unfortunately most traditional jurists also maintained that the mother would automatically lose custody of the children if she re-married, although some thought that after a certain age the child should choose which parent to live with regardless. ${ }^{5}$ In any case this pre-Qur'anic custom surrounding puberty, if it made sense back then, certainly makes no sense now, when puberty represents a very young age and corresponds to middle school for most. In any

${ }^{4}$ Lings, Martin. 1988. Muhammad: His Life based on the Earliest Sources. London: Unwin Hyman Limited, 23.

${ }^{5}$ Nasr et al. Op. Cit., 103. 
case I know of only a handful of cases, personally, where a divorced and still-single mother has succeeded in keeping her children even up to puberty, with all kinds of pressures being brought to bear on her and her family by the husband to hand them over upon divorce.

\section{The Cow, 2:234}

And those of you who die leaving behind wives, let them (the widows) remain alone [i.e. not re-marry] for four months and ten days. Then if they reach their waiting term, there is no blame upon you (pl.) in whatever they may do with themselves honourably...

Verse 2:234 above now turns the discourse from divorcees to widows, and their right to re-marry. The phrase "there is no blame", which appears often in the Qur'an and can also be translated as "no sin is incurred", always seemed curious to me. But I have come to appreciate this phrase more and more over time, and here it seems to be telling the community at large that it is not their responsibility (or business) whom these widows decide to go on to marry. As to the waiting period of four months and 10 days, this no doubt corresponds to the three menstrual cycles that divorcees also must wait out to ensure any forthcoming baby's father is not in doubt, and the additional 40 days represent the mourning period, which overturned the pre-Qur'anic custom that had often required widows to wait a full year while complying with harsh customs such as wearing the worst clothes and not bathing during that time. ${ }^{6}$

The Cow, 2:235-2:236

And there is no blame upon you (pl.) for what you have intimated to [widowed or divorced] women or hidden in your hearts. God knows that you intend to propose to them. However do not pledge yourself to them in secret, but speak in an honourable way. And do not resolve on (tying) the wedding-knot until the prescribed waiting term is complete...

There is no blame upon you ( $\mathrm{pl}$.) if you divorce women you have not yet touched nor settled on a bridal gift for [the marriage contract is not complete till the bridal gift is specified]. Provide for (these) women - the affluent according to his means, the impoverished according to his means-an honourable provision, a duty of justice ( haqqan) for those who would do good.

${ }^{6}$ Ibid. 
Verse 2:236 above is extraordinary because it seems to say that a man who enters into a marriage and then does not consummate the marriage will still owe alimony to the bride he leaves at the aisle, so to speak, even if they had not yet settled on a bridal gift-in accordance with the man's means. Notice that this relates to an unconsummated marriage where there are no infants to be cared for either, yet alimony is still owed to the wife, which tallies with God's concern in previous verses over men approaching marriage and divorce flippantly. Yet I have never come across any commentary on how magnanimous that eye-popping second half of 2:236 is.

The Cow, 2:237

And if you (pl.) divorce them (the women) before you have touched them but you had (already) settled on a bridal gift for them, then (you are liable for) half of what you had agreed on unless they (the women) forgo it or he who holds the wedding-knot [the husband, in this case] forgoes his claim [i.e. offers the full gift]. And to forgo is nearer to reverence. And do not forget (the) generosity $(\mathrm{fadl})$ between you, for God sees all you do.

Verse 2:237 above offers a concrete example of what acting with maaroof, that combination of kindness and what is considered honourable (depending on how it is used) that the Qur'an is so insistent on, can look like, and goes on to declare that acting as such is its own reward as it brings us closer to God. In the example above both the wife and the husband are encouraged to forgo their rightful half of the bridal gift when a marriage is not consummated, which becomes a mathematical impossibility if both of them choose the higher ground: if she forgoes her half then she is the more reverent one and gets zero, and if he forgoes his half then he is the more reverent one and is left with zero. So where does that leave the bridal gift, since it cannot disappear into thin air? This is one of those moments where I fall in love with the Qur'an all over again, because I do not think it is incidental that God ends this sequence with a phrase that can serve as both an instruction to be generous but also as a reminder to the couple not to overlook any generous acts between them, as though urging them to reflect and nudging back towards one another when this is the case. God in this sequence is taking the time to act as marriage counsellor, which I find a moving gesture of care and closeness. As He tells us himself: “... and $\mathrm{We}^{7}$ are nearer to it (the human being) than its jugular

7 "We" in the Qur'an is akin to the "royal we", or majestic plural. 
vein" (50:16). (More will be said about the "wedding-knot" in the next section.)

\section{The Cow, 2:240-2:242}

And (for) those of you who die leaving behind wives, a bestowal to their wives of provision for a year and (there is to be) no expulsion [from the dead husband's property]. But if they move out [i.e. re-marry], there is no blame upon you (pl.) in whatever they may do with themselves honourably. For God is Mighty, Wise.

And to divorced women (is due) a provision with kindness (bil-maaroof), a duty of justice ( haqqan) for the reverent.

In this way God makes His signs/messages clear to you (pl.), so that you may come to (use) your good sense (taaquloon).

The middle verse 2:24l above and its subject of alimony discussed in the previous commentary on 2:236 are important in that they actually established the concept of alimony to an ex-wife irrespective of whether there are children or not, until she re-marries (the latter is implied in a number of verses). Obviously alimony cannot be detailed as its amount and nature will depend on the husband's capacity, the time and the place. God here is encouraging a "provision in kindness" to ex-wives irrespective of who divorced whom ("to divorced women is due...") and not only when it is the husband initiating the divorce, as patriarchal convention has always maintained: recall that in 2:229 we are told that when the wife wants a divorce but the husband is uncooperative, she can divorce him unilaterally by giving back her bridal gift in full if need $b e$, so it is clear that a woman can initiate divorce and that God is safeguarding her right to do so by establishing the unilateral divorce $(\mathrm{kbul}$ ) as a tool of last resort if the husband will not agree to it. That a unilateral divorce by a wife of her husband is to be an act of last resort, i.e. that ideally husbands and wives would come to an agreement on the terms of the divorce, is made clear from the slew of references in the divorce verses to kindness, honourable behaviour, doing no harm, not transgressing, sacrifice, and generosity. It is generally understood that alimony would not apply in extreme cases such as proven gross abuse or infidelity by the wife. ${ }^{8}$

\footnotetext{
${ }^{8}$ See such verses as 4:19-4:20 which effectively imply the same and commentary in Asad, Muhammad. 2003. The Message of the Qur'an. Bristol, England: The Book Foundation, 65.
} 
The lengthy discourse on divorce in the Qur'an's second (and longest) chapter is then brought to a close with verse $2: 242$, which literally urges us to "come to (use) your good sense" (taaquloon), something that the Qur'an repeats at least a dozen times and which is usually translated merely as "understanding". I point out the distinction here as there are many other words for "understanding" that do not reference the mind or reason or good sense, yet this word is undoubtedly the Qur'anic favourite.

\section{Women, 4:20-4:21}

And if you (pl.) wish to exchange one wife for another and you had given one of them a significant treasure, do not take a thing from it: (or) would you take it through slander and evident sin?

And how could you (pl.) take it (back) after you have given yourselves to one another, and they (the wives) have received from you a solemn covenant?

In the above verses from the fourth chapter (the first of which affirms monogamy as the norm, as previously pointed out), God appeals to both honour and past intimacy between husband and wife to warn against a man being miserly or short-changing his wife upon divorcing her. He also reminds us that the marriage oath is a most serious one and uses the same expression ("solemn covenant") usually deployed in the Qur'an to refer to God's covenant with the Children of Israel (4:154) and with the prophets $(33: 7){ }^{9}$

\section{Women, 4:35}

And if you (pl.) fear a breach between the two of them [i.e. a married couple], then send an arbiter from his folk and an arbiter from her folk. If they wish to fix things, God will make the two of them reach agreement. For God is all-Knowing, all-Aware.

\section{Women, 4:128}

And if a woman fears rebellion (nushooz) from her husband or desertion, there is no blame upon the two of them should they make amends between them in reconciliation. And reconciliation is better, for souls are prone to greed...

${ }^{9}$ Abou El Fadl, Khaled M. 2006. The Search for Beauty in Islam: A Conference of the Books. Maryland: Rowman \& Littlefield Publishers, Inc.,170. 
In two examples of how divorce is an accepted but not encouraged solution to marital discord God recommends, to put it in modern terms, calling in mediators if necessary for a conflict resolution session. Reconciliation is urged even in the case of the above two cases, where in one case the wife (based on a previous verse) and in the other case the husband has acted with rebellion (nushooz) against the other (to be further discussed in Part V).

\section{The Confederates, 33:49}

Oh you who believe: if you marry believing women then divorce them before you have touched them, you have no (waiting) term to calculate and claim from them, so give them cause to be pleased [per 2:236-237 on their bridal gifts] and release them in a beautiful way.

And then, about half-way through the Qur'an, comes something to remind us that the plight of every individual is of concern to God, not just the wellbeing of the community as a collective, something that many of our societies have overlooked over time:

The Woman who Disputes, $58: 1-58: 4$

God has heard the words of she who disputes with you [Muhammad] regarding her husband, she who complains to God. God hears the conversation between the two of you, for God is all-Hearing, all-Seeing.

Those of you who swear off their wives by likening them to their own mothers: they are not their mothers, their mothers are those who gave birth to them. Truly they utter a senseless $\left(\right.$ munkar $\left.{ }^{10}\right)$ proclamation, and a falsehood. Yet God is all-Pardoning, all-Forgiving.

And those who swear off their wives by likening them to their mothers and then retract what they have said must free a slave [i.e. in atonement] before the two of them [i.e. the husband and wife] touch one another (again). This is what you (pl.) are counselled, and God is aware of all you do.

And he who does not have the means (to do so) must fast two consecutive months (instead) before the two of them touch one another (again). And he

\footnotetext{
${ }^{10}$ The original meaning of the often-repeated word munkar is "something that the mind/ reason rejects", yet another example (alongside taaquloon) of the emphasis the Qur'an places on using our minds. But the usual translations are indecent, dishonourable, wrong, iniquitous, which do not change the meaning materially but do sever the link with reason as such. See Asad, Muhammad. Op. Cit., 456 for this definition.
} 
who is unable (to do that) must feed sixty needy persons. This is so you may believe in God and His Messenger [i.e. Muhammad]. And these are God's boundaries...

The above opening to chapter 58 shows how seriously God takes the act of hurting a wife's feelings by making her feel undesirable, in this case through invoking an ancient oath that likened her to her mother-in-law. Apparently this was the case with a woman named Khawla (already mentioned under Chap. 1l's section entitled "Activism") who took her grievance to the Prophet. After the archangel Gabriel delivered the above four verses to Muhammad in response, he told Khawla that her husband must free a slave but she replied that he could not afford it, so he counselled that he fast the indicated two consecutive months. But she replied that her husband was too old to keep the fast, so the Prophet instructed that he feed 60 needy people instead. Again Khawla replied that her husband had nothing to give in alms. In the end the Prophet contributed a basket of dates he would soon receive as a gift and Khawla offered to contribute the same amount from her own pocket, and she was counselled to go feed 60 people on her husband's behalf so they may be reunited, which is what they both desired. (Notice that the required atonement when the wife's feelings are hurt through a verbal utterance appears tougher than it was in the very beginning of this chapter in verse 2:226, where the offence was simply swearing off touching a wife for whatever reason and the punishment was a four-month wait, period.) I tell this story $^{11}$ because in allowing the intervention of others when the husband could not atone for his sin directly, the Prophet effectively placed justice for the wronged wife ahead of punishment of the offending husband, no doubt reflecting his understanding of divine justice's own priorities.

Lastly, another set of opening verses in a short chapter actually entitled "Divorce" and devoted entirely to the subject revisits the key themes already discussed, specifically with regard to when husbands initiate divorce:

\section{Divorce, 65:1-7}

Oh Prophet: if you (pl.) divorce women, divorce them (with a view) to their waiting terms [i.e. for pregnancy-check] and keep good track of the term. And reverence God. Do not expel them from their homes [i.e. during the waiting term], nor shall they leave unless they have committed a proven

\footnotetext{
${ }^{11}$ Asad, Muhammad. Op. Cit., 959 and Nasr et al. Op. Cit., 1342.
} 
indecency (fahisha mubayyina). Those are God's boundaries...You never know: perhaps God will cause after that something new to happen.

So when they (the women) have reached their terms, either you (pl.) retain them honourably or separate from them honourably. And call to witness two just people from among you, and bear witness before God [regarding what you have decided]. Whoever believes in God and the Last Day is thus counselled, and whoever reverences God, He will find them a way out (of distress),

and provide for them from where they do not expect. For whoever puts their trust in God, He will suffice them...

As for those of your women who no longer expect menstruation, if you (pl.) are unsure, then their waiting period is three months, the same as for those who have not menstruated [the condition amenorrhea, which can still result in pregnancy]. And for those who are pregnant, their waiting term lasts until they have given birth. And whoever reverences God, He will ease their situation.

That is God's command, which He has sent down to you (pl.). And whoever reverences God, He will absolve them of their bad deeds and make their reward great.

And let them [your wives awaiting divorce] dwell as and where you dwell in accordance with your means. And do not harass them so as to make things tight for them. And if they are pregnant then spend on them until they give birth, and if they nurse your children then give them what is owed to them [per 2:233]. And consult with one another honourably, but if you make difficulties for one another, then let another woman do the nursing for him [i.e. the mother is not obliged to nurse and the father is financially responsible for the cost of foster-nursing].

Let him who has abundance spend from his abundance, and let him whose means are limited spend from what God has given him. God does not charge a soul except with what He has given it. God will (surely) grant ease after hardship.

The above introduces a new concept in the very first verse 65:1: of not kicking a wife out of the house immediately after announcing the intention to divorce her (obviously assuming the house is provided by the husband to begin with), so that the waiting term post-divorce announcement is spent in the marital home. God here is trying to give compassion and 
reconciliation a chance, as the last sentence of 65:1 makes indisputable ("You never know: perhaps God will cause after that something new to happen"). The only time God instructs that a wife is to leave the marital home during the waiting period is when she has committed a proven indecency. I have underlined this phrase because it is usually translated as "flagrant indecency" - which is not incorrect-but since another reference to indecency (fahisha) requires four eye-witnesses (verse 4:15), I think "proven indecency" is a more appropriate term, not to mention that the actual adjective used here implies "visibility" (mubayyina). Notice how verse 65:1 does not seem to expect any kind of private punishment by the husband of the wife's proven indecency beyond the wife leaving the marital home (to be further discussed in Part V).

Otherwise with regard to the curious mention in 65:4 of married women who have never menstruated but may still be pregnant and so also need to observe the pregnancy-check waiting period, I find it odd that several translations insert "yet" so that the phrase becomes "those who have not yet menstruated" (the Arabic original certainly does not include "yet"). This may give the impression that men were allowed to consummate marriage with young girls prior to menstruation-which we know was not the case for various reasons, including from Muhammad's own wait for Aisha to come of age and arguably even longer than that. The only logical meaning of this phrase is that it refers to a condition where a woman does not menstruate, ${ }^{12}$ called primary amenorrhea, yet who might be pregnant. This actually happened to a woman I know who never thought she could get pregnant because of never having had a period in her life, yet was surprised when she went on to bear a beautiful, healthy daughter when she was in her 30 s.

\section{The Pushback of Patriarchy on Women Initiating Divorce, AND on Custody Issues}

The usual claim by religious authorities is that women cannot seek a divorce, and that only a man can, for two reasons.

First, because when the Qur'an in 2:235 speaks of men wishing to marry divorced or widowed women whose waiting terms are not up yet, it tells these men not to resolve on tying the wedding-knot until they are; and when the Qur'an in 2:237 speaks of the wedding-knot, it implies that

\footnotetext{
${ }^{12}$ See also Asad, Muhammad. Op. Cit., 995.
} 
it is held by the husband. In both examples the husband is the one seeking both the marriage and the divorce, respectively, so of course it is the husband who holds the key to making or breaking the marriage! In other words, surely the Qur'an is describing how it was and not necessarily prescribing how it should be.

What more proof do we need beyond the great lengths God goes to in ensuring justice for wives in verse after verse after verse, including by granting wives a tool of last resort when the husband will not cooperate, namely the unilateral divorce $(k h u l)$, despite its Qur'anically admitted economic injustice to the woman (2:229)? In an extraordinary demonstration of how far the Prophet would go to comply with women's right to divorce under any circumstance, he is known to have ruled on a divorce in a somewhat unusual and extreme case, when a woman named Jamila came to him regarding her husband to say:

By God! I do not dislike him for any fault in his character or faith, but I dislike his ugliness. By God, if I had no fear of God, I would have spat in his face when he came to me. O Messenger of God! You see how beautiful I am and that Thabit is an ugly man. I don't blame him for his faith or character, but I fear becoming [a bad believer]. ${ }^{13}$

Even in this case that had no other grounds but personal dislike of physical looks which was moreover expressed most cruelly and certainly without a trace of kindness or maaroof by the woman, the Prophet still granted Jamila her divorce, although given the circumstances I am not surprised that he first asked her if she would give the man back the garden he had given her, so that it was effectively a unilateral divorce not requiring negotiation with Thabit. When Jamila responded that she was prepared to give more than that, the Prophet responded no, just the garden. He then, as de facto jurist, ordered Thabit to accept both the unilateral divorce and its settlement. ${ }^{14}$

Yet most of us grow up hearing that the "wedding-knot" ( 'isma) is a right to divorce that is held by the husband alone, and not a figure of speech, and that it means he can execute a divorce easily with or without cause. Whereas a woman with an uncooperative husband cannot usually initiate a divorce unless:

${ }^{13}$ Lang, Jeffrey. 1995. Struggling to Surrender: Some Impressions from an American Convert to Islam. Maryland: Amana Publications, 159.

${ }^{14}$ Ibid. 
- She throws herself at the religious courts' mercy by making a good case for wanting the divorce (recall that a man seeking divorce is not even asked to provide a cause) - a gruelling process and true Pandora's box depending on the country, culture, school of jurisprudence, and presiding jurist. For example, verbal abuse or preventing a woman from studying or working may not be considered serious enough by a court depending on the where, how, why or who of the judicial process.

- She invokes verse 2:229 to obtain a unilateral divorce ( $\mathrm{hhul}$ ) by giving up her bridal gift in full ${ }^{15}$ as well as her Qur'anically mandated right to alimony, thereby immediately dissolving the marriage-a process that could possibly complicate any custody negotiations. However, even the less-than-just (in most cases) unilateral divorce mechanism has been "edited" for the worse by religious authorities, with most Muslim-majority countries now requiring a wife to obtain her husband's permission for her "unilateral" divorce to take effect! ${ }^{16}$

- She is knowledgeable, brave, and strong enough to have insisted on being designated co-holder of the wedding-knot ( ${ }^{\prime}$ sma) in the marriage contract, to get round the surreal transformation of a Qur'anic description of an observed situation (where men had mostly made the divorce decision) into a permanent legal fixture in an Islamic marriage contract.

The simple and quite obvious solution to all of the above is to stop assuming that the wedding-knot is held by the husband alone by default. But given how prevalent this belief and custom is, the only way to do it now would be to write into the very structure of every Islamic marriage contract an explicit clarification that both parties jointly hold the wedding-knot ( 'isma) so that either of them can initiate divorce, so that the unilateral divorce that the Qur'an grants women goes back to being a tool of last resort as originally intended, as opposed to the only way for a woman to free herself when she is the one who wants out. This is the only fair way forward, which ensures that all related considerations

${ }^{15}$ al-Hibri, Azizah. 2000. An Introduction to Muslim Women's Rights. In Windows of Faith: Muslim Women Scholar-Activists in North America, ed. Gisela Webb, 70. New York: Syracuse University.

${ }^{16}$ Ibid., 71. 
of bridal gift, alimony and possibly even custody can be processed through the proper Qur'anic methods we have been given.

As for the question of custody and visitation rights when there are children involved, there can be no whitewashing how awful and even cruel so many societies have been in denying divorced mothers custody of their children to some degree or other, often also limiting their visitation rights. There can be only one protection against this within a Qur'anic marriage: that custody and visitation rights of the children in case of divorce be stipulated upfront in the marriage contract. After all that's what these nuptial contracts are for, and we have had them at our disposal longer than any other community on the planet. If this turns out to be an issue for the prospective groom, then the prospective bride will at least know before it is too late whether they have enough values in common to proceed with the marriage or not.

Second, because all the divorce narratives in the Qur'an revolve around the case where men are initiating the divorce, and there is no narrative outlining what should happen when it is the women initiating it. In other words as with interfaith marriage, the claim is that the Qur'an is silent about women initiating divorce and therefore it must mean that they cannot. Even verse 2:229 which speaks of women divorcing unilaterally is dismissed as a specific instruction for a particular case where the husband had initiated (an unfair) divorce to begin with! This is a vivid example of downright refusing to absorb the message while scurrying about to fulfil instructions unthinkingly. As with the case of interfaith marriage, could it not be that God was simply focusing on the problem at hand, in this case that of husbands mistreating their wives through abandonment and unfair or recurring divorces? The sheer number of verses on the topic of divorce and the creative variety of unfair practices we are treated to surely speak for themselves-or do we need every one of those verses also articulated in reverse gender roles in a wildly hypothetical set of scenarios where the wives are the ones doing the abandoning and divorcing of their husbands unfairly and repeatedly, to get the point that whatever principle applies to one human being necessarily also applies to the other? Once again a single tree reigns supreme, never mind the forest or the entire message. 


\section{The Pushback of Dogma When Men Initiate Divorce: Three Months for You, But Just Three WORDS FOR ME!}

We have seen how the divorce verses make frequent reference to the waiting term required of wives after a divorce is announced to ensure the identity of an unborn child is not thrown in doubt, and that this term is defined as three menstrual cycles in 2:228. So if a wife already has in mind marrying someone else, for example, it can only happen after this term is honoured.

We have also seen that when a man announces that he is divorcing his wife, he is not to expel his wife immediately (assuming the property is his to begin with) and must also maintain her as before until the waiting term is up and in accordance with his finances, as detailed in 65:1 and 65:6.

If the husband changes his mind during this waiting period and revokes his divorce announcement, then all is well. If he changes his mind again however, and announces his intent to divorce a second time, then he only has one last chance to keep his wife (respectfully) because if he were to announce divorce a third time, which would be effective at the end of the waiting period, then that would be final per 2:229-230. After that any thought of revoking his stance is out of the question and he only becomes eligible to marry her again if she has meanwhile married and divorced another man $(2: 230)$, as though to teach the whimsical man a lesson!

So basically the initial expression of wanting to divorce is equivalent to the modern "separation" phase, except that the Qur'an instructs that the couple continue to live together for at least three menstrual cycles afterwards while abstaining from sexual relations, probably to encourage the rethinking of things while limiting the potential for conflict over parentage should the woman turn out to be pregnant. During this time (typically three months) there is room for a change of heart by the husband, but up to a point: there is a clear intention here by God to limit flippancy and abuse by husbands of the divorce and waiting mechanism, as we have seen.

So what happens in reality?

First, there is a tendency to completely ignore the Qur'an on living together for three months to let things settle, whether biologically or emotionally, even as the three months' waiting period is imposed on 
the wife but not on the husband, who is regarded as free to go off and get married to someone else right away! This is justified by arguing that the Qur'an references the waiting term in relation to the wife for biological/pregnancy reasons, but not the husband, though no one ever mentions the very opening of the chapter entitled "Divorce" that tells the divorcing husband not to expel his wife from their home for the duration of the waiting period while not harassing or pressuring her. Or are we to believe it would be alright for him to marry another woman and bring her into the same house, that this would not constitute harassment and pressure? Nor would a husband be off the hook if he had a second home and could afford to maintain his wife as before even as he moved on with his life with another woman, for that is surely missing the point of verses 65:1 and 65:6 with regard to a cooling-off period.

Second, and more curious, has been the inversion of a Qur'anic divorce guideline. The Qur'an never told husbands that they must declare their intention to divorce three times for it to take effect: declaring it just once, and not going back on that declaration at the end of the three-month waiting period, would be sufficient. God told them, rather, that they could change their minds about a divorce they have initiated only twice during the waiting term/cooling off period, a clear bid to make them behave responsibly. In any case the result is that a husband seeking a divorce usually rushes to utter the divorce proclamation as fast as possible three times in a row, taking no more than three seconds probably, without feeling the need to honour the three months because he has already been absolved from it anyway through the argument that it is a women's thing, as just mentioned. I vividly remember a scene from one of the many excellent Egyptian films I watched growing up, when I was about 10 or 11 : a troubled married couple is in a heated exchange and the man then declares "You are divorced!", and the music takes a dramatic turn for a few seconds as the woman is stunned and begins trembling and pleading "No!", followed by another "Divorced!" and the music is raised a notch and the woman is now besides herself and in tears, and then the final blow comes as the man utters for the third time the word: "Divorced!" - and both the music and wife are now at their most excruciating expressions of distress... all within less than a minute or so. 
Open Access This chapter is licensed under the terms of the Creative Commons Attribution 4.0 International License (http://creativecommons.org/licenses/ by $/ 4.0 /)$, which permits use, sharing, adaptation, distribution and reproduction in any medium or format, as long as you give appropriate credit to the original author(s) and the source, provide a link to the Creative Commons licence and indicate if changes were made.

The images or other third party material in this chapter are included in the chapter's Creative Commons licence, unless indicated otherwise in a credit line to the material. If material is not included in the chapter's Creative Commons licence and your intended use is not permitted by statutory regulation or exceeds the permitted use, you will need to obtain permission directly from the copyright holder.

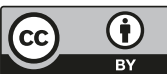

